Politeness inferences in Jesus' Discourse with his Lord:

\title{
A Dialogic Analysis
}

\section{Yasser Fawzi Abd al-alim Rateb}

\begin{abstract}
The current research presents the manifestations of politeness phenomena in a 'talk-in-interaction' between Prophet Iesa the son of Mary (Jesus), and his Al-Mighty Lord. The study embraces Leech's (1983) 'politeness principle' model. Moreover, it infers what speakers mean from what they say which is essential in highlighting politeness phenomena as crucial basis for interaction. Consequently, findings affirm the fact that Jesus has manipulated the best linguistic utterances that have marked his politeness with his Lord.
\end{abstract}

Key words: dialogue, dialogue analysis, inferences, Jesus, Lord, politeness.

\section{Introduction}

Prophets' dialogues are essential components of communicative interactions in the Holy Qur'an. Hence, they seek to manipulate the best linguistic utterances that enable them to interact politely with their Lord. Thus, Jesus' discourse can be inferred as one in which language has been performed to affirm politeness phenomena. Therefore, in his talk with his Lord, Jesus' dialogues are also referential in marking his polite discourse. This paper presents politeness phenomena through, the specific use of some utterances by Prophet Jesus in a dialogic discourse with his Lord in Surah number five in the Holy Qur'an, that is, the Surah of Al-Ma'idah (The Table Spread with Food).

\section{Materials and Methods}

Materials are derived from the Noble Qur'an, specifically the Surah of Al-Ma'idah (The Feast Table). This material is also adopted from Al-Hilali and Khan 2007 translation of the Noble Qur'an. Therefore, the dialogic interaction between Jesus and his Lord is extracted and analyzed in terms of Leech's politeness principles. The current paper's main focus is on 'absolute politeness; which does not stick interlocutors to a specific 'context'; it is, therefore, the Prophetic kind of politeness. That is, all kinds of politeness persist, by and large, in this noncontextualized kind of politeness; in this regard, as a Prophet and Messenger of his Lord, Jesus dialogic communicative interaction is characterized by this absolute politeness. Therefore, it is convenient, then, to analyze his dialogic interaction with his Lord. Accordingly, Leech's 
model (1983) of 'absolute politeness' is functionalized as a linguistic frame in terms of dialogue analysis approach.

\subsection{Leech's 'Politeness Principles'}

Brown and Levinson's $(1978,1987)$ model of politeness can be identified as the most famous book, amongst others, in analyzing politeness in terms of 'face' (Short 2014, p. 352). Yet, this paper adopts Leech's (1983) model, as it is tightly related to dialogic interactions, that is, it fits the discourse of the 'self' and the 'other', which is the main constituent of Qur'anic 'talks-in-interaction'. Moreover, Leech's 'politeness principle' is composed of some maxims which give the interpretation of how politeness works in dialogic talks. For him, "politeness provides a missing link" (Pan 2000, p.8) between Grice's maxims and the function of speech acts in dialogic communicative interactions. Moreover, the two politic theories can be inferred as the result of being the fact that dialogic communicative interactions are, by and large, 'goal-oriented', and interlocutors' primary interactional aims are to reach to a grasp of their mutual handling of these aims. Leech (1983, pp.83-4) thinks of politeness in terms of two main kinds: 'relative politeness' and 'absolute politeness'. Hence, the former is closely related to the 'context' or the situation, while 'absolute politeness' is, therefore, regarded as an entire attribute of a speaker disregarding the context of the discourse. At the same time, he divides this kind of politeness as 'negative politeness', which implies the "minimiz[ation] of impoliteness of impolite illocution", as well as 'positive politeness', which is able, by and large, to increase "the politeness of polite illocution" (ibid, pp.83-4). Accordingly, Leech affirms the fact that 'negative politeness' is more effective than 'positive politeness, as it mitigates the imposition of an utterance; in other words, it absorbs the impolite inferences of impositions (e.g. orders), whereas 'positive politeness' increases the politeness phenomena in an utterance (e.g. offers), (ibid, p.81).

In this respect, Leech identifies his politeness principles into two doctrines: 'interpersonal' as well as 'textual rhetoric'. The former is related to the social affinities amongst interlocutors, whereas the latter is specified with the textual stylistic enterprises. Accordingly, Leech makes up six 'maxims' that form his tenet of politeness, that is, these principles identify the relationship between the 'self' and the 'other' in a dialogical sense. These maxims are the 'tact maxim' which specifies the utterance in terms of 'cost-benefit' between interlocutors. Therefore, in order that the 'self' can be polite, s/he has to maximize the benefit to the 'other', and, at 


\section{Yasser Fawzi Abd al-alim Rateb}

the same time, to minimize the cost to the 'other', too. Accordingly, the 'generosity maxim' is also connected to 'cost-benefit' affinity, that is, the 'self' has, by and large, not only to minimize benefit, but also to increase cost to his/her own 'self'. And in the same vein, 'approbation maxim' is joined to the increase of 'praise', as well as the decrease of 'dispraise' of the 'other'. Moreover, the Leechian 'modesty maxim' is tightly correlated with treating the 'self' humbly, that is, to decrease the 'praise' of the 'self', and in the same respect, to grasp the notion that the 'self' has not to be highly praised. This can be inferred, according to Brown and

Levinson' (1987, p.61), as a strategy of 'seeking agreement' and 'avoiding disagreement'. In other words, Leech positions it as the 'agreement maxim' which maintains the dialogical affinity between the 'self' and the 'other', that is, the 'self' is polite, if s/he is able to interact accordingly with the 'other', that is, to seek accordance, and to avoid discordance. In this way, the 'self' will be able to 'minimize antipathy', as well as 'maximize sympathy' between his/her own 'self' and the 'other' (ibid, 1983, p.132).

\subsection{What is Dialogue Analysis}

The field of analyzing dialogues is "a dominant approach to the study of ... interaction"; therefore, this area is, by and large, a 'multidisciplinary' domain which is crucially stuck to sociology, linguistics, as well as communication (Sidnell and Stivers 2013, p.1). Thus, it is a scope of exploring and maintaining the interpersonal affinities. Moreover, this field can also be interpreted as a way of finding out the 'commonalities' and 'patterns' of dialogic communicative interactions (Graumann 1995; Drew and Curl 2008). Hence, dialogue analysis is primarily "interested in the dialogic nature" of linguistic variables (Jucker, Fritz, and Lebsanft 1999, p.1). In other words, dialogue analysis can be inferred as an area that is based on discovering the multiplicity of 'epistemic status' and the 'epistemic stances' which interlocutors hold. Thus, the function of this 'science' is to help in grasping, as well as anatomizing the linguistic inferences in the discourse of interlocutors. In this respect, interlocutors' knowledge is also a crucial direction to the analysis of dialogue. In other words, the dialogic interaction constitutes a multiplicity of interlocutors' epistemology; therefore, the variety of this 'ontological' typology is, by and large, the domain of dialogic inferences which, in turn, are the main topic of analysis. So, the variety of knowledge enhances the dialogic actions, and, at the same time enriches the dialogic scene that is essential in marking politeness phenomena between the 'self' and the 'other'. In this respect, Maranhao (1990) maintains that dialogue is "ethical in the Self's turning 
to the "Other'" (p.18). Consequently, the genre can be inferred as the anatomy and the conceptualization of the dialogic constituents of discourse, such as utterances, turns, initiations, responses, and 'sequentiality organization'.

\section{Data Sources}

Data is extracted from Surah number five (Al-Ma'idah), i.e. the 'Feast Table' in the Noble Qur'an. Most of this Surah is primarily dedicated to maintaining the five pillars of Islamic Law (i.e. religion, 'self', honor, property, and mind) ${ }^{1}$. And it is named like this, as the people of Jesus have asked him to request his Lord in order to send down this table that is spread with food as a proof of his Prophet-hood. Jesus asks them to "Fear Allah, if [they] are indeed believers." (v.112:5, in AlHilali and Khan 2007, p. 235). Hence, despite the fact that his Lord sends the table down, they do not believe in Jesus. Thus, The Lord will interrogate Jesus - on the Day of Resurrection - if he has asked his people to worship him, as well as his mother, instead of his Lord (cf. the dialogue below).

116. And (remember) when Allah will say (on the Day of Resurrection): "O 'Iesa (Jesus), son of Maryam (Mary)! Did you say unto men: 'Worship me and my mother as two gods besides Allah?' "He will say: "Glory be to You! It was not for me to say what I had no right (to say). Had I said such a thing, You would surely have known it. You know what is in my innerself though I do not know what is in Yours, truly, You, only You, are the All-Knower of all that is hidden and unseen.

117. "Never did I say to them aught except what You (Allah) did command me to say: 'Worship Allah, my Lord and your Lord.' And I was a witness over them while I dwelt amongst them, but when You took me up, You were the Watcher over them, and You are a Witness to all things. (This is a great admonition and warning to the Christians of the whole world).

118. "If You punish them, they are Your slaves, and if You forgive them, verily You, only You are the All-Mighty, the All-Wise ."

119. Allah will say: "This is a Day on which the truthful will profit from their truth: theirs are Gardens under which rivers flow (in Paradise) - they shall abide therein forever. Allah is pleased with them and they with Him. That is the great success (Paradise). 120. To Allah belongs the dominion of the heavens and the earth and all that is therein, and He is Able to do all things.

(Al-Hilali and Khan 2007, pp. 236-7)

${ }^{1}$ http://www.jabriweb.net/index.php/2015-03-22-22-21-36/actueel/604-2015-07-19-13-48-46. 


\section{Analysis and Discussion}

The above selected data is to be analyzed in terms of the above stated linguistic methods; the study adopts Dialogue Analysis ${ }^{2}$ as an approach in accordance with Leech's (1983) politeness maxims. Therefore, the interpretation and the explanation of politeness phenomena will be investigated in terms of the dialogic features in the discourse of the 'self' and the 'Other' in which the 'self' seeks all politeness aspects in order to win the Consent of the 'Other'. Accordingly, due to the fact that it is an "address-oriented speech rather than speaker-oriented speech" Suomala (2014, p.13), in terms of Leech's 'tact maxim', Jesus' initiates a dialogic deference and reverence to his Lord, that is, he glorifies Him. In other words, Jesus venerates his Lord out of any shortage that can be stuck to His Al-Mighty. Therefore, he initiates with his Lord's Sublime Nature; that is, there is no parallel to His own 'Self'. Hence, "... There is nothing like unto Him ..." (v.11, 12:42, in Al-Hilali and Khan1984, pp. 652-3). Moreover, this glorification can be inferred in terms of Leech's maxim of approval which magnifies the exaltation of the 'Other'. In this respect, 'deference' can also be inferred as the "humbling of the 'self' or the [glorification] of the [O]ther's [S]elf" (Brown and Levinson (1978, 1987, p.81). Thus, when Jesus confirms the factual 'Epistemic Status' of his Lord saying: that; "You know what is in my inner-self ..." (V.116:5, in Al-Hilali and Khan1984, p.168), while he has no knowledge of his Lord's 'Self', this can be inferred as humbling the 'self', though $\mathrm{He}$ is Rich and 'Worthy of all Praise', in front of the Glorified 'Other'. Moreover, Jesus also asserts that he has not told his people, except what he is allowed to say, not more; this can be inferred in terms of 'absolute politeness' or as deference. Therefore, Jesus' utterances are 'relevant', as well as "informative...for the current purpose" (Grice 1975, p.45). Hence, in case a messenger is loaded with a specific message, and he delivers it honestly as it is, his action can, then, be thought of as a kind of deference to the third 'other'. In this way, Jesus asserts that he has transmitted his Lord's Message, that is, they have to worship Him Alone, as $\mathrm{He}$ is his Lord and He is their Lord, too. Accordingly, Jesus' concluding assertions at the end of his turns can also be inferred in terms of Leech's 'approbation maxim' which maximizes the praise of the other; in this way, Jesus glorifies his Lord saying that $\mathrm{He}$ is the All-Knower of the unseen; He is a 'Witness to all things'; He is the All-Mighty and the AllWise. Hence, Jesus' glorification of his Lord can, thus, be inferred as 'absolute politeness', in Leech's terms, due to his maximization of praising the 'Other'. In the same respect, Jesus confesses that his

${ }^{2}$ Mick Short's (2014) terms; turn-taking patterns, speech-acts patterns, and politeness phenomena 
knowledge is nothing if compared to his Lord's; so, in terms of 'epistemic status', as well as 'epistemic stance', that is, the Lord is the All-Mighty, the All-Knower of the unseen, the All-Wise; the All-Seer, and the AllHearer. Hence, it is the knowledge of the 'eternal universals' which can, by and large, be trusted as 'true knowledge' (Markova 2003, p.7). In contrast, Jesus' knowledge -despite the fact that he is a Messenger, and is supported by his Lord's Graces ${ }^{3}$-- is 'ontologically' less, in part and all, than his Lord's epistemology. Therefore, in terms of Leech's maxim of approval the 'self' increases glorification of the Other's Knowledge, that is, he is totally controlled by the All-Knower of all things, Who "... knows the fraud of the eyes, and all that the breasts conceal" (v.19:40, in Al- Hilali and Khan1984, p. 633). Besides, Jesus also asserts that he has been commanded by his Lord to say specific things, thus, in terms of Leech's 'generosity maxim', Jesus increases charge to his own 'self', that is, he is deemed to fulfill specific missions in regard to his Lord's Commands. So, unconditioned obedience can be inferred as 'absolute politeness', as well. Moreover, Jesus expresses his gratitude to his Lord as he is located as a 'witness' over his people, that is, he affirms that he has been just a 'witness', and his Lord is the All-Watcher. Therefore, in terms of Leech's 'authority scale', which counts, by and large, the point of "distance in terms of power" (p.126). Jesus, then, positions himself though he is chosen by his Lord, in a modest place, due to his Lord's Power which controls the whole universe ; "it is He Who gives life" (v.2:57, in Al-Hilali and Khan1984, p.739); and He also causes death; the whole universe is His Kingdom ${ }^{4}$. Therefore, it can also be inferred, in terms of the 'self', as 'praising' the 'Other', as He has unparalleled properties as well as absolute Authority over His addresser (Jesus) ${ }^{5}$. In this regard, Jesus is fully aware of his Lord's Power and Authority, and his own modest position in front of his Lord; hence, his politeness can be inferred in terms of the 'self'-low-praise, and the 'Other'-highglorification. Moreover, Jesus' minimization of self-praise, and the maximization of his Lord's exaltation, can also be inferred in terms of Leech's maxims of approval and modesty, which is, therefore, inferred in this way as 'absolute politeness', which is not affixed to situational dialogic interactions. Hence, Jesus' assertive politeness utterances, thus, originate from his confidence in his Lord's Omnipotent Attributes which are his beliefs. Thus, assertions can have the ability to "maintain the speaker's norms [and] beliefs" Labinaz and Sbisa (2014, p.32). Therefore,

${ }^{3}$ V. 110: 5, in Al-Hilali and Khan 1984, p.166.

${ }^{4}$ Ibid, v. 3, 4, 5: 57, p.739.

${ }^{5}$ Ibid, v. 255:2, p.57. 


\section{Yasser Fawzi Abd al-alim Rateb}

this way of interaction can, then, be inferred as 'absolute politeness'. In other words, trusting others, as well as embracing their beliefs and 'norms', can, thus, urge the 'self' to interact in an 'absolute politeness'; accordingly, the 'self' thinks of the 'other' in an 'ontological' tenet, that is, the 'self-in-the-other', or, in other words, the dependence of the 'self' on the 'other' (cf. Markova 2006, p.127). in doing so, Jesus seeks the Reward of his Lord; he aspires to get, though he is set in great graces in Lifetime $^{6}$, a better position amongst other Prophets in the Hereafter. Moreover, Jesus discourse can be inferred, as a course of, in Leech's terms, 'maximizing agreement' between his own 'self' and the 'other'; thus, his assertions are, by and large, factual, as they have the 'illocutionary force' of fulfillment, due to his Prophetic position? Accordingly, Labinaz and Sbisa affirm that assertions are performed by a speaker who is located in a special position that enables him to interact in such way (ibid, p.43). In the same respect, Jesus has been bestowed special graces from his Lord; therefore, his assertive utterances are the outcome of this position. Hence, it can be inferred as a way of gratitude for his Lord's Graces upon him. Therefore, the 'self' being grateful for the 'other' can, then, be inferred as an 'absolute politeness'. Thus, Jesus' indirectness is also a high reference to his 'absolute politeness', too. That is, indirectness is closely connected with 'absolute politeness' (cf. Cutting 2002, p.20). In his dialogic interaction, indirectness dominates his discourse with his Lord, that is, most of his utterances are, by and large, indirect assertive acts which maintain his undertakings and commitments (cf. MacFarlane 2009, p.80). Therefore, in the beginning of his talk, Jesus glorifies his Lord, that is, exalting Him from any unreal human claims, and he refutes the claims which his people have afflicted Him with ${ }^{8}$. In this regard, Jesus has not just freed himself of their claims; however, at the end of his discourse, he has politely related the whole matter of punishment to the All-Mighty, the All-Wise, as people accusations are afflicted to the Oneness of Allah; and He may forgive or torment them. In this regard, it can be inferred in terms of Jesus' sympathy with his Lord, that is, accusing Him of begetting a son is a great $\sin ^{9}$. In this sense, Jesus maximizes sympathy with his Lord, as he has not asked forgiveness for his people who have invented lies ${ }^{10}$ against his Lord, Who neither begets, nor is He begotten, and on Whom all His Creatures depend (cf. Surah

\footnotetext{
${ }^{6}$ V.45:3, in Al-Hilali and Khan 1984, p.74.

${ }^{7}$ Ibid, v.85:6, p.183.

${ }^{8}$ Ibid, v. 30:9, p.248.

${ }^{9}$ lbid, v. 88-95, pp.412-13.

${ }^{10}$ V. 21:6, in Al-Hilali and Khan 1984, p.172.
} 
112, in Al-Hilali and Khan1984, pp.584-5). In brief, Jesus' dialogue is mainly characterized by indirect utterances which have the inferences of 'absolute politeness'. Moreover, Jesus has been grateful to his Lord, so, he has sought to increase his kindness and thankfulness to his Generous Lord Who has chosen him and supported him by His Angels ${ }^{11}$. Moreover, he frees his own self from the non-factual accusations of his people. He initiates his dialogue with glorification, asserting his Lord's Sublime Attributes, that is, $\mathrm{He}$ is the All-Knower of the unseen; $\mathrm{He}$ is the AllWise; He is the All-Watcher of all things; He is the All-Witness over all things; however, his people invent lies against the All-Mighty Lord. Thus, Jesus asserts that he has delivered His Messages honestly as He has commanded him, not more.

\section{Conclusion}

Politeness inferences are the core of the linguistic variables of the Holy Qur'an. That is, the Qura'nic discourse implies all kinds of politeness, 'relative politeness', i.e. context-bound politeness, as well as 'absolute politeness' which is freed from any dialogic restrictions. Therefore, Jesus' discourse has been characterized by the latter kind, that is, he has performed utterances which have implied his 'absolute politeness'. Moreover, the variety of 'epistemology' has also been significant in Jesus' inferential utterances. Hence, he is a well-prepared Prophet and Messenger whose discourse is politely directed to his Lord. Moreover, Jesus is the word of his Lord ${ }^{12}$ who has, then, been a tactful slave, as he has increasingly mentioned the Attributes of his Lord; he has been generous, as he has committed himself not to ask forgiveness to claims inventors; he has shown consent to his Lord's Orders, and decreased the praise of his own 'self' and increased the praise of his Lord; he has also been modest in his own 'self'-esteem as well as appreciation, and the 'Other's-esteem and appreciation. Jesus has also sought agreement, as it is, by adopting politeness phenomena that are the incentives of the fulfillment of any dialogic 'talk-in-interaction'. 


\section{Yasser Fawzi Abd al-alim Rateb}

\section{REFERENCES}

Al-Hilali, M. \& Khan, M. (Trans), (1984). The Noble Quran: Interpretation of the Meanings of the Noble Qur'an in the English Language.

Medinah: King Fahad Complex for the printing of the Holy Qur'an.

Al-Hilali, M. \& Khan, M. (Trans), (2007). The Noble Quran: Interpretation of the Meanings of the Noble Qur'an in the English Language.

Riyadh: Dar-u-salaam publishing .

Brown, P. \& Levinson, C. (1978, 1987). Politeness. Some universals in language usage. Cambridge: Cambridge University Press.

Cutting, J. (2002). Pragmatics and discourse: A resource book for students. London: Routledge.

Drew, P. and Curl, T. (2008). Conversation analysis: Overview and new directions. In Vijay K. Bhatia, J. Flowerdew \& R. H. Jones. (Eds.). Advances in Discourse Studies. New York: Routledge. pp.22-51.

Graumann, C.F. (1995). Commonality, mutuality, reciprocity: A conceptual introduction. In I. Markova \& C.F. Graumann, \& K. Foppa. (Eds.). (1995). Mutualities in Dialogue. Cambridge: Cambridge University Press. pp. 1-24.

Grice, P. (1975). Studies in the way of words. Harvard \& London: Harvard University Press

Heritage, J. (2013). Epistemics in Conversation. In Sidnell,J and Stivers,T. (2013). (Eds.). The Handbook of Conversation Analysis. (pp.370-394 ). Oxford: Wiley-Blackwell.

Jucker, A.H., Fritz, G. \& Lebsanft F. (Eds.). (1999). Historical dialogue analysis: Roots and traditions in the study of the romance languages, German and English. Amsterdam: John Benjamines.

Labinaz, P. \& Sbisa, M. (2014). Certainty and uncertainty in assertive speech acts. In A. Zuczkowski et al. (Eds.). Communicating Certainty and Uncertainty in Medical Ssupportive and Scientific Contexts. Amsterdam: Benjamines. pp. 31-58.

Leech, G. (1983). Principles of pragmatics. London: Longman.

Leech, G. (2014). The pragmatics of politeness. Oxford: O.U.P.

MacFarlane, J. (2009). What is assertion? Oxford: Oxford University Press. 


\section{Politeness inferences in Jesus' Discourse with his Lord: A Dialogic Analysis}

Maranhao, T. (ed.). (1990). Introduction. In T. Maranhao. (1990). (ed.). The interpretation of dialogue. Chicago \& London: University of Chicago Press.

Marková, I. (2003). Dialogicality and social representations: The dynamics of mind. Cambridge: Cambridge University Press.

Marková, I. (2006). On 'the inner alter' in dialogue. International Journal for Dialogical Science. Vol. 1, No. 1, 125-147.

Pan, Y. (2000). Politeness in Chinese face-to-face interaction. Vol. 60. Stamford: Albex publishing company.

Short, M. (2014). Analysing dialogue. In P. Stockwell \& S. Whiteley (Eds.), The Cambridge Handbook of Stylistics (Cambridge

Handbooks in Language and Linguistics, pp. 344-359). Cambridge:

Cambridge University Press. doi:10.1017/CBO9781139237031.026.

Sidnell, J. and Stivers,T. (2013). (Eds.). Introduction. In J. Sidnell and T. Stivers (2013). (Eds.). ( $1^{\text {st }}$ edition). The Handbook of Conversation Analysis. Oxford: Wiley-Blackwell. pp. 1- 8.

Suomala, K. R. (2014). Moses and God in dialogue: Exodus 32-34 in post biblical literature. New York: Peter Long. 